\title{
Teenagers Premarital Sex Phenomenon In Banjarmasin
}

\author{
Esti Yuandari ${ }^{*}$ \\ ${ }^{1}$ Sari Mulia School of Health Science, Banjarmasin, Indonesia \\ *yuandariesti@gmail.com \\ Umi Hanik Fetriyah ${ }^{1}$ \\ ${ }^{1}$ Sari Mulia School of Health Science, Banjarmasin, Indonesia \\ umi_hanik_f04@yahoo.co.id
}

\begin{abstract}
Objective: This study is to identify the background and factor of the problem

Technology or Method: This study adopted qualitative approaches descriptive explorative. The population of the research is all teenagers in Banjarmasin, while the sample techniques to research is by using judgment sampling.

Result: The research results show that premarital sex among teenagers is influenced by internal and external factor. The internal factor is influenced by the teenagers' lack of reproductive health sex education, while externally the parents and schools lack effort to prevent premarital sex. The source of wrong information used by the youth to acquire knowledge about sex education, so that teenagers obtain negative information about sex education and the results are the shift value and norms regarding the premarital sex among teenagers.

Conclusion: Behavior of premarital sex among all these teenagers is something considered to be common in establishing relationship. Absence of firm rules of the government, shifting value and cultural norm, abuse of source of information, and less maximum supervision of the school environment and families become the main occurrence of premarital sex behavior in adolescents.
\end{abstract}

Keywords: phenomenon, premarital, sex, teen

\section{INTRODUCTION}

Teenagers are potentially high human resources. Their awareness of reproductive health is important for growth as they begin to explore with themselves, their role identity values, and their behavior. In the matter of sexuality, teenagers are often confused with the changes that occur in him. Many phenomena that show some teenagers do not know and understand about reproductive health. [1]

Unhealthy sexual behavior among teenagers, especially unmarried teenagers tend to increase. This is evident from some research results that adolescence, when they first had an active sexual relationship, varied between the ages of 14-23 years, and the most age is between 17-18 years. Sexual behavior in adolescents can be manifested in a variety of behaviors, ranging from feelings of interest, holding 
the genitals under the shirt, to perform coitus. [2]

According to Green [3] a person's behavior is influenced by three factors, namely predisposing factors, supporting factors, and driving factors. Modernization, globalization, technology and information as well as various other factors also influence behavior change. Even with the growing external influence, especially information that can harm, such as premarital sex that allows teenagers to switch between partners, increased number of teenage pregnancies and young marriage. In addition, premarital sex is a great opportunity for teens to have an abortion, as well as contracting sexually transmitted diseases (STDs). The National Commission on Child Protection surveys in 33 provinces from January to June 2008 concluded that 1). $97 \%$ of junior high and high school adolescents never watch porn movies, 2). $93.7 \%$ of junior high and high school adolescents have kiss, genital stimulation (genital stimulation) and oral sex (sex by mouth), 3). 62.7\% of junior high school teenagers are not virgins, 4). $21.2 \%$ of adolescents admitted to having had an abortion. [4]

Based on data from Banjarmasin City Health Office, the number of free sex among teenagers has increased drastically compared to 2013 data. Until the end of 2014 there is an increase in teenagers.
From as many as 50 people in 2013, jumped to 235 people by 2014 . Other data occurred in cases of KTD (Unwanted Pregnancy), from 352013 people, soaring to 220 in 2014. [5]

\section{RESEARCH METHODS}

The research design used in this research was descriptive explorative qualitative approach. Population in this research is all adolescent in Banjarmasin City. The sampling technique used in the research was Judgment Sampling.

\section{RESULTS}

\section{Characteristic of the Informant}

1. Main Informants

Table 1 Characteristics of main informants

\begin{tabular}{ccccc}
\hline No & $\begin{array}{c}\text { Informants' } \\
\text { codes }\end{array}$ & $\begin{array}{c}\text { Ages } \\
\text { (year) }\end{array}$ & Genders & Status \\
\hline 1. & I1 & 19 & Male & Student \\
2. & I2 & 15 & Female & Student \\
3. & I3 & 15 & Female & Student \\
4. & I4 & 18 & Male & Student
\end{tabular}

2. Triangular Informants

Table 2 Characteristics of Triangular Informants

\begin{tabular}{ccccc}
\hline No & $\begin{array}{c}\text { Informants' } \\
\text { Codes }\end{array}$ & $\begin{array}{c}\text { Ages } \\
\text { (years) }\end{array}$ & Genders & \\
\hline 1. & IK1 & 44 & Male & DinKes \\
2. & PS1 & 41 & Female & Guru BK \\
3. & PS2 & 30 & Female & Guru BK \\
4. & OT1 & 45 & Male & Orang Tua \\
5. & OT2 & 47 & Female & Orang Tua \\
\hline
\end{tabular}

\section{Premarital Sex Behavior Among}

Adolescents.

The development of the era that has caused the decline of social values, as well 
as the rise of pornographic videos that can be easily accessible underlying teenagers to perform premarital sex behavior as disclosed by the informant: as follows:

“It's just to show our love..... at present sex is a common thing.... moreover pornography is easy to get from the internet" (I1)

Young women usually have premarital sex because they are forced and persuaded by their partners with various promises and hopes to be loyal and responsible, and try to be a partner that can provide comfort for their partner.

Shifting values and norms in society is one of the background of premarital sex behavior in adolescents, as revealed by the two informants.

Premarital sex among teenagers is one proof to show affection and loyalty to their partners. Usually they have sex in locations that are considered safe as in boarding house, friends' house, at home, and the location is considered safe and quiet as disclosed the following informants:

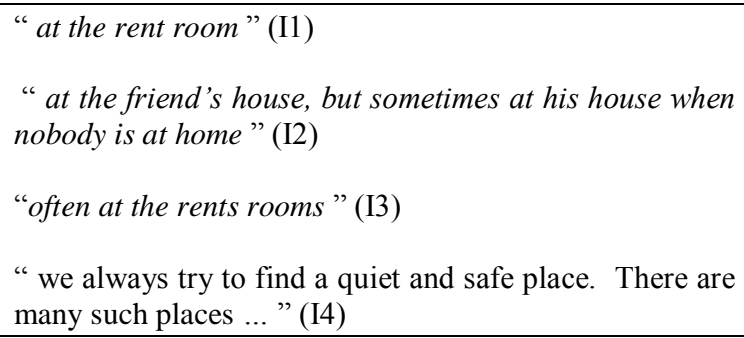

Adolescents say they have sex as long as they have a bond with their partner or courtship, as the following informants said:

"of course with my lover " (I1)
“ with my present boy/girl friend, but I used to do it with my ex." (I2)

"only with my lover" (I3) and (I4)

Sex is an activity they can do when meeting with the support of possible situations and conditions that they consider safe, as revealed by the following informants:

"I can do it twice or three times a week, or every time we meet at the rent room" (I1)

"we do it sometimes, depending on the situation, if the house is possible" (I2)

"it can be often, especially when we meet, we usually go to the rent room" (I3)

" quite enough.....only when I feel like doing it" (I4)

Physically premarital sex behavior can lead to venereal disease, pregnancy out of wedlock or unwanted pregnancies. Psychologically premarital sexual behavior can cause psychological trauma, especially in women, whereas psychosocial women will be greatly excommunicated or rejected in both the community and the family themselves. as disclosed below:

"I regret it, but what can I do? It's common at present, isn't it? " (I1)

" frankly speaking I regret it, but I love him/her. I am willing to do anything as long as I am not separated from him/her" (I2)

"it's useless to regret, just do it. What is important is that we are always together" (I3)

"I don't feel sorry. It's just that he is in love with me" (I4)

The value and social shift of a development of the times and the increasing sophistication of information technology that is easily accessible whenever and wherever, and the assumption that premarital sex is a form of 
expression of love, affection and faithful, and sexual intercourse is one way to maintain relationships in order to survive long.

\section{Factors Influencing Premarital}

\section{Sexual Behavior Among Teens}

\section{a. Internal Factor}

1) Knowledge

Proper knowledge of sex education and the impact of premarital sex, is expected to prevent premarital sex behavior.

\section{Teens knowledge about sex}

Lack of knowledge about early sex education can cause adolescents to fall into the wrong sex behavior, so they perceive the meaning of sex based on their understanding, as revealed by the informant:

“ having sex...........emmm....as long as doing it with
love, no problem" (I1)
“ having sexual intercourse is ok as long as without
force" (I2) dan (I4)
"having sex with our boy'girl friend is no problem, but
not with other people" (I3)
Based on the above data, it can be concluded that the perception of adolescent about sex is doing body relationship activity with the opposite sex even though not legally religious, as long as done on the basis of love, affection, likes, no coercion, and done with partner.

Adolescent knowledge about the impact of premarital sex behavior
Premarital sex behavior has an impact that can damage the lives of adolescents, especially when viewed in terms of health. The following statement from the informants about the impact of premarital sex behavior:

"getting genital disease, afraid of being pregnant" (I1) dan (I4)

“ kgetting HIV/AIDS, ...I am pregnant and the family members are notified, I can be kicked out. " (I2)

"the impact is bad enough, such being pregnant, vaginal discharge, HIV/AIDS, being not virgin" (I3)

From the above interviews on the impact of premarital sexual behavior, it can be concluded that teenagers actually know about the impact of premarital sex, such as venereal disease, pregnancy, HIV / AIDS and loss of virginity, even the most worried is the social impact of being evicted by the family and isolated by society and have a bleak future.

a) Teen's knowledge about avoiding the impact of premarital sex

Lack of adolescent knowledge about reproductive health and inadequate sex education can result in adolescents trying to excite the arousal of desire due to hormonal dynamics in the wrong way. Various efforts they do to avoid the danger of premarital sex, following the statement of informants about the prevention of premarital sex hazards:

“...using condom..." (I1) and (I4)
" using a condom and don't change partners, clean
ourselves afterwards" (I2)
"using condom because it easy to get at the shops or
dispensary" (I3)


"using a condom or cum outside to avoid being pregnant" (I4)

Adolescent understanding of the prevention of premarital sex hazards can be said to be the same by using contraceptives such as condoms and not mutually couples, as well as by washing to clean the intimate area after completion of contact, which they consider able to prevent the occurrence of danger from premarital sex.

\section{b. External Factor}

\section{1) Source of Information}

Lack of information obtained by teenagers about premarital sexual behavior and the impact it generates through formal channels from school environments, health workers, parents, makes teenagers find out for themselves about it. This causes teenagers to obtain information that is less precise about sex education, plus the rise of negative information obtained through peers, as disclosed informants as follows:

“.from the internet because technology is
advanced......just search... and you got it. " (I1) and (I4)
" when hanging out with friends, we chat about sex, and
from the internet ...." (I2)
"from the school, friends, and from the internet ... " (I3)

Adolescents have an overestimate perception of peer behavior, so peer perception is a stronger determinant of the occurrence of behavioral deviations that would pose a risk. Teenagers generally choose peers based on their own behavior or known as "flocking phenomenon".

\section{2) The role of the school}

Providing correct information on sex education and reproductive health in school subjects as well as counseling and counseling units (BK) is expected to provide appropriate information to teenagers about it. As disclosed below:

"... if the school, it is implemented from the subject of
biology ... the material is discussing about the adolescent
reproductive system, there is also from health agencies
or from health colleges that provide counseling about
reproductive health, it wrote usually..." (BK1)
"usually from biology lessons, same seminars or
outreach activities, usually from campus health
campus.." (BK2)

Information provided by the school about sex education to adolescents is implemented in Biology lessons and seminars or outreach activities from both health agencies and health institutions. In addition to providing information on sex education, the school also made several programs and policies to prevent premarital sexual behavior on students and students who will have an impact not good also on the good name of the school, as revealed by the informant triangulation follows:

“.. the school has strict rules on behavior that will
tarnish the school's reputation, the most heavy out of
school ... we provide some exclusive activities such as
drum band, Basketball, Futsal, PMR, Scout, Ball, Dance,
Band, Etc .. with activities it is expected that they focus
more on school activities" (BK1)
"we have a regulation that must be obeyed ... if breaking
the rules is not too heavy usually only parent calling, but
heavy reply that make good school name is polluted yes
sanction is expelled from here ... activity there is also
spiritual activities same religious lesson, in there they
will know what the consequences if this.."(BK2)


Various efforts to prevent premarital sex behavior in adolescents conducted by the school so far has been implemented maximally, both from the school itself and through outsiders. From the school itself, they already have strict rules, if teenagers commit acts that violate the rules will be processed in accordance with their mistakes ranging from parent calling, until the most emphatically is expelled from school. And also with the lessons about reproduction, they are expected to get information about sex education early on correctly. Besides, with the existence of extra-curricular is expected to form a teenager's personal toward a more positive coupled with the existence of spiritual activities for all religions will be very helpful in increasing faith for adolescents, so that will fortify themselves from bad deeds.

\section{The role of the parents}

Adolescence is a transitional period in which teenagers are trying to find out who they really are, at this time teenagers are very vulnerable affected by things that are negative and often adolescents in view as children who are not tidy, not trustworthy, tend to behave destructively, causing people adults must guide and supervise the lives of adolescents. Parents do give responsible freedom, but it should be as their parents to know where their children are going or at least what activities their children do outside the home, so as to prevent premarital sex behavior in adolescents. such as the following interview:

"I never forbid the origin of freedom that I give is not abused for negative things. because this adolescence is indeed again its time looking for identity, yes one of them by having a partner. As long as it does not go wrong it does not matter.". (OT1)

"If the way out is allowed, especially for school activities, but although given the freedom must be responsible. If out of the house must know where it goes? With whom? Go home on time, if out nights do not come home more than $9 \mathrm{pm}$. If prohibited cannot either, so allowed wrote origin must be smart just in case. ". (OT2)

Many things parents do to prevent their children not to do premarital sex behavior. There are parents who curb their children and there are even parents who do not allow their children to go out before college. However, there are also parents who give freedom and allow their children dating even though still in high school. It was disclosed by the respondent's parents as informant triangulation as follows:

"Yes, if the right courts do not mix. Think school first, courtship may come from school not to be neglected". (OT1)

"Tau know to be careful if dating, be smart take care, do not be alone with your lover, do not go home too late. What is certain if the courtship must know the limitations". (OT2)

Parents hope that given the freedom that is responsible and giving advice to the 
child is able to avoid premarital sex behavior in adolescents.

\section{Health Office}

Banjarmasin City Health Office as an institution of municipal government having social status or status in society in carrying out its duties and authority related to efforts of spreading sexually transmitted diseases has been done in various ways, as expressed by informant triangulation as follows:

".. it is a scourge for all of us, actually already many programs that we have socialized to the teenagers through socialization, counseling, coaching, and campaigns both through mass media and electronic.. (DK)

Many efforts have been made by the Department of Health through policies in conducting activities related to premarital sex behavior in adolescents and anticipate transmission of sexually transmitted diseases caused by premarital sex behavior both in the program and with crosssectoral. as revealed by the informant as follows:

".. in Banjarmasin itself is actually very overthrow, the program that we socialize not only in the city environment, but already looted to the suburbs as well ... ... the need for rules in the form of regional regulations that regulate the impact of premarital sex.... (DK)

There are several factors inhibiting the Health Office to maximize and realize the programs that have been prepared especially the role of the community as the principal actors and observers of the environment need to be improved again:

".. the role of preventing premarital sexual behavior is not just our job, but it needs support from all parties, especially the community itself, then from the family environment, and from the school environment, so that if there is no active role from all the lines .. this case will be more rampant, plus access to information containing negative content is easier to access.. (DK)

Prevention is not only done by the same government, but also need oversight on the home environment, school environment, such as teachers or public who happened to see odd things done by teenagers should be monitored until things do not happen unwanted.

\section{DISCUSSION}

\section{The Background of Premarital}

\section{Sexual Behavior Among Teens}

Based on the research results obtained information that adolescents perform premarital sexual behavior because of a shift in values and norms in society, especially among adolescents who assume that it is a common thing and commonly done at the time of courtship and is the proof of affection or a sense of love for his partner. In addition, the existence of the hope given from the lover for her partner to have sexual intercourse to be one of the reasons teenagers, especially girls. Usually they do not want to break the relationship with his partner just like that. They try to keep their relationship to last. Premarital sex behavior in teenagers usually they do at home friends who live alone and it is done with their girlfriends. 
The various behaviors that lead to the satisfaction of the sex drive basically indicate the unsuccessful person in controlling or shifting the impulse to another activity that is actually workable [6]. Several studies related to Indonesian adolescent life in general conclude the values of adolescent life is in the process of change, namely the tendency to tolerate premarital sexual life style. [7]

Premarital sex behavior occurs because of internal factors as well as external factors. Premarital sex behavior occurs not only because of the biological impulse which is a natural instinct of the functioning of the reproductive organ system and the work hormone, but also the existence of influence from outside Lack of knowledge even the wrong concept in adolescents about reproductive health and sex education is also true is one of the internal factors the occurrence of premarital sex behavior.

Opening the opportunity teenagers do premarital sex behavior is also supported by some things such as the lack of attention of parents to their children and even many parents who think that sex education or reproductive health is something that is considered taboo to be discussed even parents tend to make the distance

The influence of peers is so strong that the appearance of deviations from sexual behavior is associated with peer group norms. In addition, the phenomenon of premarital sex behavior in adolescents in Indonesia itself is like a culture of corruption, which is not recognized existence but the fact has become a "habit" or "system".

\section{Factors Influencing Sexual Behavior} Among Teens

\section{a. Internal Factor}

Youth knowledge about sex education tends to be low. In addition, as the times progressed, the free sex culture was not taboo. The phenomenon of free sex culture in society is similar to the culture of corruption, not recognized its existence, but the fact that it has become a habit in Indonesia. Adolescents must accept the fact that the free sex culture has become the new identity of Indonesian adolescents.

While the impact of premarital sexual behavior of adolescents revealed that sexual behavior can lead to either the physical impact of pregnancy, causing sexually transmitted diseases or HIV, the loss of virginity or virginity, psychological effects such as stress and distress other than premarital sexual behavior has a psychosocial impact isolated or cornered either in the family or in the community. In addition, prevention efforts to avoid pregnancy or sexually transmitted diseases, the use of contraceptives such as condoms, do not change the couple, and washing the femininity after completion of the relationship is considered capable of preventing it.

According to Syafrudin (2008), half knowledge is more dangerous than not knowing at all. The formation of knowledge itself is influenced by internal factors namely the way individuals respond to such knowledge and external stimulus to change that knowledge becomes even better. [8] Half of knowledge leads teenagers to seek 
information from others or sources that are unclear or even wrong at all.

\section{b. External Factor}

\section{Source of Information}

The source of information about sex education is through teachers, the internet, books and friends. Lack of information about true sex education and a sense of high curiosity teens make teenagers trying to find out themselves through mass media and peers so they get the wrong information or negative.

This suggests that the lack of information received by teenagers on the subject of sex education from sources that can provide accurate and accountable information services. In addition, adolescent sexual activity and behavior are heavily influenced by technological advances, such as print and electronic media. (Tukiran et al, 2010).

Teenagers who are in the period of wanting to know and want to try, will imitate what is seen or heard from the mass media, because in general have never known the full sexual problems of parents or from school. With pornography, the brain will experience hyper stimulating so the brain does not work normally, even very extreme which can then make it smaller and damaged [9]. Adolescents who engage in premarital sex behavior can be motivated by the influence of groups (peers) in an attempt to become part of the group by following the norms that have been embraced by the group including premarital sex behavior. In addition, it is driven by a great curiosity to try everything that is not yet known [10]. Then, proximity to peer groups is very high because the peer group ties tend to replace family ties, is also a source of affection, sympathy, and understanding, sharing experiences and as a place of adolescence to achieve autonomy and independence. Thus adolescents have a tendency to adopt information received by their friends, without having a significant information base from a more reliable source. [11]

Results of research dr. Donald Hilton, a prominent surgeon from the United States, concluded that if cocaine could damage the brain in three parts, then pornography or sex addiction would damage the brain in five parts. This means, the pornographic damage to the brain is more powerful than drugs. [12]

\section{The Role of the Family}

Based on the results of parenting research on children, adolescents say that parents provide responsible freedom to their children. It is the same as revealed by parents. Typically, parents are more intensive attention to young women than male teenagers. Providing advice and freedom responsible to adolescents are expected to prevent premarital sex behavior.

Experts argue that the best education is through parents to their children. In talking about sexual issues that are very personal and require a close and heart-to-heart atmosphere between parent and child. This would be easier to create between a mother and her daughter or a father with her son, even if it is not possible to be realized when done between mother and son or father with a daughter. Based on research conducted by 
Fox and Inazu in Sarwono (2012) shows the result that the need for sex education for adolescents, especially those done by parents. This study revealed that the more frequent conversation about sex between mother and child, the child's sexual behavior will be more responsible. [13].

Parenting patterns of parenting is an interaction between children and parents during holding parenting activities. This parenting means parents educate, guide, and discipline and protect children to reach maturity in accordance with the norms that exist in the community. Here are three parenting patterns that parents apply to children according to Santrock (2003). Authoritarian parenting, Authoritative parenting, and Permissive parenting patterns Permissive parenting patterns. [14]

The role of communication in the family is very important as a vehicle for transferring cultural values and transformation agents. Communication can take place both vertically and horizontally between parents and their children. The need for affection and attention from parents in any case and support to the hobby so that adolescents are able to develop their talents and channel their activities to more positive things in order to prevent premarital sex behavior.

\section{The Role of the School}

As a formal educational institution, schools not only provide technical skills (hard skills) but also on the ability to manage themselves and others (soft skills). According to the Ministry of National Education, 2010 character education should bring learners to the recognition of values cognitively, appreciating values affectively, and ultimately to actual value practice. Character education that has to be studied soon, and sought alternative solutions, and need to be developed more operational so easy to implement in school. [15]

Based on the results of the study, the school has been trying to educate students to have good behavior, not only to prevent premarital sexual behavior but also so that students can be a character person who is able to choose or have the right attitude to take decisions in behaving. The existence of extracurricular activities, counseling guidance, even spirituality activities performed to prevent premarital sex behavior. Specific information about reproduction is usually delivered by biology teachers. besides religious education also emphasizes character education for their students.

\section{The Role of Health Office}

The government is also obliged to make various activities to channel the skills and talents of students and children. As Article 24 and 25 of Law no. 40/2009 is implemented in a planned, systematic, and continuous way to increase the potential and quality of physical, mental, spiritual, knowledge, and self and organizational skills towards youth independence. Through increased faith and piety; improvement of science and technology; the organization of state defense and national defense; affirmation of youth economic independence; improvement of the quality of 
the body, art, and culture of youth; and / or conducting research and mentoring activities of youth. [16] In South Kalimantan, especially Banjarmasin, the incidence of abortion caused by pre-marital sex cases is increasing from year to year, this becomes a challenge for the provincial government of South Kalimantan in general and the Health Office in particular that become regional institutions that fight the problems of human health status in Banjarmasin. Various policy programs to overcome these problems have been undertaken by the local government, especially the health service through counseling and seminars, youth empowerment policy, although the domain of the government, but is a joint responsibility with other institutions.

\section{CONCLUSION}

Based on the results of research on premarital sex behavior in adolescents in the city of Banjarmasin it can be concluded that premarital sexual behavior that rampant occurs in adolescents caused by several reasons or background including the shift of value and social development of an era and sophisticated information technology, as evidence or a sign of affection they are against their partner, the expectation given by their partner, Values that assume that premarital sexual behavior is common and prevalent during dating, proximity to peer groups is very high tend to replace family ties, is also a source of affection, sympathy, and understanding, sharing experiences and as a place for adolescents to achieve autonomy and independence. High curiosity encourages a tendency to adopt information received by friends, without having a significant information base from a more reliable source.

\section{REFERENCES}

[1] Aden. 2010. Ketika Remaja dan Pubertas Tiba. Yogyakarta: Hanggar Kreator.

[2] Sarwono W.S. 2007. Psikologi Remaja. Jakarta: RajaGrafindo Persada.

[3] Green, W, Lawrence.et.al. Heatth Education Planing A Diagnostik Approach. The. Johns Hapkins University: Mayfield Publishing Company, 2005

[4] BKKBN. 2009. Panduan pengelolaan Pusat Informasi dan Konseling Remaja. Jakarta

[5] Dinas Kesehatan Kota Banjarmasin. Profil Kesehatan Kota Banjarmsin. Tahun 2015.

[6] Tarwoto dkk. 2010. Kesehatan Remaja : Problem dan Solusinya. Jakarta: salemba medika.

[7] Suryoputro, A, Nicholas J.F, Zahroh S. (2006). Faktor-Faktor yang mempengaruhi Perilaku Seksual Remaja di jawa Tengah: Implikasinya Terhadap Kebijakan dan Layanan Kesehatan Seksual dan Reproduksi. Makara Kesehatan.

[8] Syafrudin. 2008. Remaja Dan Hubungan Seksual Pranikah. http://id.shvoong.com/medicine-andhealth/1799376-remaja-danhubungan seksual-pranikah/. Diakses pada tanggal 26 Juli 2017.

[9] Niskala S . 2011. Agar Seks Tidak Salah Jalan Pendidikan Seks yang Benar untuk Remaja. Jakarta Timur: Progressio Publishing 
[10] Azwar, Saifuddin. (2005). Sikap Manusia : Teori dan Pengukurannya; $\quad$ Yogyakarta; Pustaka Pelajar.

[11] Branstetter, S. A. "Parental Monitoring and Adolescent Drug Use Frequency, Control Problem, and Adverse Consequences" University of Denver Departement of psychology. NIDA Grant F31 DA015030-01, 2003.

[12] Hilton, Donald L, Jr \& Clark Watts (2011). Pornography addiction: A neuroscience perspective. Surgical Neurology International, 2(19). doi: 10.4103/2152-7806.76977

[13] Sarwono, S. W. Psikologi Remaja. PT Raja Grafindo Persada. Jakarta, 2012

[14] Santrock, Adolescence (2003). Perkembangan Remaja. Alih Bahasa oleh : Shinto B. A. dan S. Saragih. Penerbit Erlangga. Jakarta

[15] Kementerian Pendidikan Nasional. 2010. Panduan Pendidikan Karakter di Sekolah Menengah Pertama.

http://goeroendeso.files.wordpress. com/2011/09/panduan-pendidikankarakter-di-smp.pdf. Diakses tanggal 26 Juli 2017

[16] Undang-Undang Republik Indonesia Nomor 40 Tahun 2009. Kepemudaan, Generasi Muda, atau Pemuda. Jakarta 